\title{
The DOF Transcription Factors in Seed and Seedling Development
}

\author{
Veronica Ruta, Chiara Longo, Andrea Lepri, Veronica De Angelis, Sara Occhigrossi, \\ Paolo Costantino and Paola Vittorioso *(ID)
}

Department of Biology and Biotechnology, Sapienza University of Rome, P.le Aldo Moro 5, 00185, Rome, Italy; veronica.ruta@uniroma1.it (V.R.); longo.493622@studenti.uniroma1.it (C.L.);

lepri.1689102@studenti.uniroma1.it (A.L.); deangelis.1695787@studenti.uniroma1.it (V.D.A.); occhigrossi.1634553@studenti.uniroma1.it (S.O.); paolo.costantino@uniroma1.it (P.C.)

* Correspondence: paola.vittorioso@uniroma1.it; Tel.: +39-0649912265

Received: 20 January 2020; Accepted: 6 February 2020; Published: 8 February 2020

\begin{abstract}
The DOF (DNA binding with one finger) family of plant-specific transcription factors (TF) was first identified in maize in 1995. Since then, DOF proteins have been shown to be present in the whole plant kingdom, including the unicellular alga Chlamydomonas reinhardtii. The DOF TF family is characterised by a highly conserved DNA binding domain (DOF domain), consisting of a $\mathrm{CX}_{2} \mathrm{C}-\mathrm{X}_{21}-\mathrm{CX}_{2} \mathrm{C}$ motif, which is able to form a zinc finger structure. Early in the study of DOF proteins, their relevance for seed biology became clear. Indeed, the PROLAMIN BINDING FACTOR (PBF), one of the first DOF proteins characterised, controls the endosperm-specific expression of the zein genes in maize. Subsequently, several DOF proteins from both monocots and dicots have been shown to be primarily involved in seed development, dormancy and germination, as well as in seedling development and other light-mediated processes. In the last two decades, the molecular network underlying these processes have been outlined, and the main molecular players and their interactions have been identified. In this review, we will focus on the DOF TFs involved in these molecular networks, and on their interaction with other proteins.
\end{abstract}

Keywords: DOF proteins; seed germination; DELLA proteins; seed maturation; seedling development

\section{Introduction}

The first DOF (DNA binding with one finger) proteins were isolated because of their interaction with viral or bacterial sequences [1-3]. Indeed, the maize DOF1/MNB1a was originally identified as a protein binding to the cauliflower mosaic virus 35S (CaMV35S) promoter [1,4]; similarly, the Arabidopsis OBP1 (ocs Binding Factor/OBF BINDING PROTEIN 1) was shown to bind an element upstream of the ocs domain present in the CaMV35S promoter [2]. The tobacco NtBBF1 (Nicotiana tabacum rolB domainB Factor1) DOF protein was identified as the plant transcription factor binding to the promoter of the plant oncogene rolB [3], where it recognises a specific sequence in the region required for rolB expression in root meristematic cells and for induction by auxin $[5,6]$. All DOF proteins bind the highly conserved (T/A)AAAG consensus motif, identified through binding site-selection experiments using the maize DOF proteins DOF1, DOF2, DOF3 and PBF (PROLAMIN BINDING FACTOR) [7]. Although these first DOF proteins have been linked to viral and bacterial activity, subsequent studies highlighted their fundamental role in plant-specific processes (for a review, see References [8-10]).

In this review, we will focus on the role of DOF proteins in seed and seedling developmental processes.

In Arabidopsis, seed development is divided in two phases: embryo/endosperm development and seed maturation [11]. Once the embryo is formed and cell division arrests, the seed enters the 
maturation phase characterised by an increase of the levels of abscisic acid (ABA) required for the establishment and maintenance of dormancy upon completion of maturation. Germination occurs when seeds are in optimal environmental conditions, mainly as far as water availability, light and temperature [12,13], and dormancy is released-under experimental conditions, dormancy can be released by a period of storage and a cold treatment at $4{ }^{\circ} \mathrm{C}$ for two days (stratification). The positive effect of light on seed germination is mediated mainly by the Red-light photoreceptor phytochrome $B$ (phyB) [14], which controls the balance between ABA, which promotes dormancy, and gibberellic acid (GA), which stimulates germination by counteracting the effect of ABA [15-17]. Once germination is completed, seedling development undergoes photo- or skoto-morphogenesis, depending on the presence or absence of light, respectively [18]. An in-depth analysis of these processes is covered in other articles of this issue.

\section{DOF TFs Regulate Seed Storage Protein Accumulation and Mobilisation}

In cereal seeds, Prolamins are the main class of storage proteins in starchy endosperm cells. They are characterised by a region rich in proline and glutamine and are synthesised in the endoplasmic reticulum during seed development. The expression of prolamin genes is tightly controlled. The main cis-element present in their promoters is an endosperm-specific box $[19,20]$, which consists of two motifs: a GLM (GCN4-like motif) (5' G(A)TGA(G) GTCAT 3') that shares homology with yeast GCN4 [21], and a 7 bp P-box (Prolamin box) (5'TGTAAAG3') [22-24]. The endosperm nuclear factors binding the P-box on the promoters of barley prolamin genes were among the first DNA binding factors identified in plants [25-28]. The corresponding PBF (PROLAMIN BINDING FACTOR) gene was first isolated from maize and shown to encode a DOF protein that interacts with O2 (Opaque2) [29]. The barley and wheat homologues of maize PBF-BPBF and WPBF, respectively-were shown to interact in vitro with the P-box motif present in the promoter of the barley Hor2 (Hordein-2) gene, encoding a barley prolamin [30] (Table 1). The GLM motif is recognised and bound by bZIP (basic leucine zipper) transcription factors of the $\mathrm{O} 2$ sub-family [31-34]; indeed, mutations of the maize $\mathrm{O} 2$ gene result in a endosperm-specific decreased expression of the genes encoding the maize prolamin proteins, named zeins $[35,36]$. The barley bZIP proteins, BLZ1 and BLZ2, were shown to bind the promoter of the Hor-2 gene [32,34]. Transient expression experiments in barley endosperm showed that BLZ1 and BLZ2 transactivate a synthetic promoter containing both the GLM and the P-box motifs through homo or heterodimer formation [32,34], and that the presence of the P-box motif was required for this transactivation [34]. Conservation of this DOF-bZIP molecular module is also suggested by the cooperation of the rice PBF orthologs (RPBF) with the bZip transcription factor, RISBZ1, in inducing the expression of the storage protein genes in rice [37].

BPBF has also been shown to interact with GAMYB, a barley transcription factor belonging to the R2R3 MYB family [38], which binds a 5' AACAAC 3' element, close to the endosperm-specific box. In barley endosperm, GAMYB cooperates with BPBF to induce expression of the Hor2 gene [38], and the in vivo interaction between the two proteins has been shown in onion cells by means of the BiFC (bimolecular fluorescent complex) approach [39]. Interestingly, the same authors proved that, besides BPBF, the barley DOF protein, SAD (SCUTELLUM and ALEURONE-expressed DOF), was also able to bind the Hor2 promoter and to interact in vivo with GAMYB [39]. Accordingly, the simultaneous presence of both these DOF proteins in co-transfection experiments, resulted in an additive trans-activation effect [39].

Besides storage proteins, endosperm also contains starch, which is crucial for both seed yield and quality. The maize ZmDOF36 protein has been recently demonstrated to positively control starch accumulation [40]. Indeed, ZmDOF36 overexpressing lines showed upregulation of starch biosynthetic genes and increased starch content. In addition, six of these biosynthetic genes, namely ZmAGPS1a, ZmAGPL1, ZmGBSSI, ZmSSIIa, ZmISA1 and ZmISA3, were directly bound by ZmDOF36, in a yeast one-hybrid assay [40]. Similarly, it was previously shown that knock-down of the endosperm-specific 
ZmDOF3 gene results in reduced starch content in endosperm of the ZmDOF3 RNAi transgenic lines [41].

Lipids are also important seed storage compounds, mainly in oil crops such as soybean, maize and cotton. The soybean DOF proteins GmDOF4 and GmDOF11 have been shown to directly induce the acetyl CoA carboxylase and long-chain-acyl CoA synthetase biosynthetic genes [42]. Consistently, lipid and total fatty acids content was increased in GmDOF4 and GmDOF11 transgenic Arabidopsis seeds [42]. Similarly, overexpression of GhDOF1 from Gossypium hirsutum resulted in an increase of lipid levels in cotton seeds [43].

At the onset of seed germination, stored compounds, mainly proteins and starch, are hydrolysed by proteases and hydrolytic enzymes secreted from aleurone cells [44,45]. GAs induce the expression of these proteases- and hydrolases-encoding genes: the promoters of these genes are characterised by a conserved GA response complex (GARC), comprising three cis-acting motifs: a GA-responsive element (GARE), a DOF binding site and a TATCCAC box [46,47]. GAs also induce transcription of the GAMYB transcription factor, which binds the GARE box $[48,49]$. GAMYB trans-activation is counteracted by BPBF which, besides inducing prolamin genes, has been shown to repress the Al21 gene, encoding a cathepsin B-like protease, through binding to the DOF binding site of the GARC [50]. Interestingly, SAD is also involved in the control of Al21 expression, but with an antagonistic function with respect to BPBF [51]. Indeed, in regulating the expression of hydrolase genes in aleurone cells, $\mathrm{BPBF}$ functions as a repressor, whereas SAD functions as a transcriptional activator, although both interact with GAMYB [50,51]. Moreover, two additional DOF proteins, HvDOF17 and HvDOF19, have been shown to negatively control the GAMYB-mediated expression of the Al21 gene in germinating barley aleurones and to interact with GAMYB. HvDOF19 binds the three DOF binding sites present in the Al21 promoter to repress Al21 in an ABA-dependent manner, whereas HvDOF17 functions by reducing the GAMYB affinity for the GARE box, following HvDOF17-GAMYB direct interaction [52] (Table 1).

Table 1. DOF (DNA binding with one finger) genes involved in seed storage protein accumulation and mobilization.

\begin{tabular}{cccc}
\hline Name & Species & Function & References \\
\hline PBF & Zea mays & $\uparrow$ prolamin genes & {$[29]$} \\
BPBF & Hordeum vulgare & $\uparrow$ hordein genes & $\downarrow$ hydrolase genes \\
& & $\uparrow$ hordein genes & {$[30,39,50]$} \\
SAD & Hordeum vulgare & $\uparrow$ hydrolase genes & {$[39,51]$} \\
HvDof17 & Hordeum vulgare & $\downarrow$ hydrolase genes & {$[52]$} \\
HvDof19 & Hordeum vulgare & $\downarrow$ hydrolase genes & {$[52]$} \\
WPBF & Triticum aestivum & $\uparrow$ prolamin genes & {$[30]$} \\
RPBF & Oryza sativa & $\uparrow$ prolamin genes & {$[37]$} \\
\hline
\end{tabular}

Reported in the table are the DOF proteins characterised as Prolamin Binding Factors, the species, the function and the references. The up arrow means transcriptional activation, whereas the down arrow means transcriptional repression. PBF (PROLAMIN BINDING FACTOR), BPBF (Barley PROLAMIN BINDING FACTOR), WPBF (Wheat PROLAMIN BINDING FACTOR), RPBF (Rice PROLAMIN BINDING FACTOR), SAD (SCUTELLUM and ALEURONE-expressed DOF).

\section{Interaction DOF-DELLA Represses Seed Germination}

DELLA proteins are repressors of GA signalling and of GA-mediated processes, such as seed germination. In Arabidopsis, there are five DELLA-encoding genes, namely RGA, GAI, RGL1-3 (REPRESSOR OF ga1-3, GA INSENSITIVE, RGA LIKE 1-3). DELLA repression is relieved following GA binding to the GID1 (GA-INSENSITIVE DWARF1) soluble receptor [53,54]. DELLA proteins are bound by the GA-GID1 complex and are subsequently recognised by the F-box SLY (SLEEPY) protein, which targets DELLAs to degradation via the ubiquitin-proteasome 26S pathway [54,55]. DELLA proteins do not directly bind DNA but act through interaction with the DNA-binding domain of transcription 
factors, thus blocking their transcriptional activity [56-58]. DELLAs can also activate transcription by sequestering inhibitors $[59,60]$.

As for the seed germination process, it was shown that the DELLA protein primarily involved in this process is RGL2 [61-63]. A genome-wide comparative study allowed us to identify genes specifically regulated by RGL2. This analysis compared the transcriptome of ga1-3 rga-t2 seeds-which are not able to germinate-with that of ga1-3rga-t2rgl2-1, in which a lack of RGL2 results in the rescue of seed germination [63]. Analysis of the promoters of the upregulated Differentially Expressed Genes (DEGs) revealed a significant enrichment in DOF binding sites, thus suggesting that RGL2 might interact with DOF transcription factors to induce expression of the target genes [63]. Further studies on the RGL2 target gene GATA12, encoding a GATA zinc finger transcription factor, led to the identification of the RGL2-DOF6 (At3g45610; DOF3.2/DOF6) complex responsible for GATA12 induction in freshly harvested seeds. The direct interaction between RGL2 and DOF6, demonstrated by a yeast two-hybrid assay, was confirmed by Co-IP (Co-Immunoprecipitation) in Nicotiana benthamiana leaves [64]. GATA12 is a downstream repressor of GA-mediated seed germination, and it contributes to the establishment of seed dormancy. ChIP (Chromatin Immunoprecipitation) assays proved that both RGL2 and DOF6 are required to induce GATA12 expression [64] (Figure 1).

DOF6 was previously shown to negatively affect seed germination, increasing both the ABA level and the expression of ABA-related genes in seeds [65]. By yeast two-hybrid and bimolecular fluorescent complementation assay in onion cells, it was also demonstrated that DOF6 interacts with the positive regulator of germination TCP14 (TEOSINTE BRANCHED1/CYCLOIDEA/PROLIFERATING CELL FACTOR14), thus suggesting a competitive action of these two transcription factors during dormancy and germination of seeds [65]. TCP14, which has been shown to promote GA-mediated cell proliferation during seed germination, directly interacts with both GAI and RGL2, which inhibit the DNA-binding activity of TCP14, thus inactivating its positive effect on seed germination [66].

Although it was proposed that neither RGA nor GAI plays a major role in controlling GA-dependent seed germination [67], extensive genetic analysis with different combinations of della mutant alleles clearly revealed that, in addition to RGL2, RGA and GAI also repress seed germination, and that their function is light-dependent [68]. The molecular mechanism of this control was unveiled by $\mathrm{Oh}$ and collaborators [69], who showed that $G A I$ and $R G A$ are transcriptionally induced in the dark by PIF1 (PHYTOCHROME INTERACTING FACTOR1), the master repressor of seed germination [70]. In the light, PIF1 is degraded via the proteasome $26 \mathrm{~S}$ and, in turn, the expression of GAI and RGA is downregulated [69].

Another DOF protein, which represses seed germination through direct interaction with a DELLA protein, is DAG1 (DOF AFFECTING GERMINATION 1), which was convincingly demonstrated to be involved in seed germination [71]. Indeed, dag1 knockout mutant seeds show reduced dormancy and require lower Red-light fluence rates than wild-type seeds to germinate [71,72]. In addition, dag1 mutant seeds require about a ten times lower GA concentration than wild-type to reach $50 \%$ germination [72]. DAG1 acts in the phyB-mediated pathway, downstream of PIF1, and it controls the ABA/GA ratio by repressing the GA biosynthetic gene GA3ox1 and the ABA catabolic gene CYP707A2 [73,74]. 


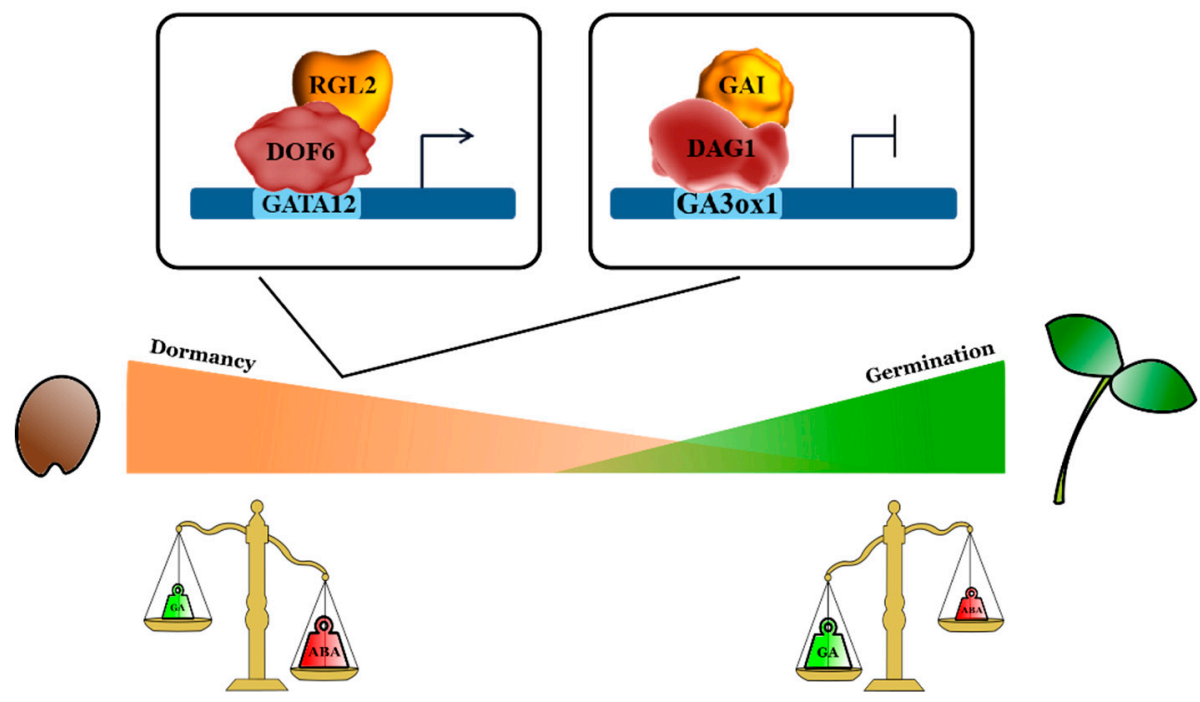

Figure 1. DOF proteins interact with DELLA factors to negatively regulate seed germination. On the left: the Arabidopsis DOF6 protein (AT3G45610; DOF3.2) interacts with the DELLA protein RGL2. The complex RGL2-DOF6 induces GATA12 expression, in freshly harvested seeds, to establish seed dormancy [64]. On the right: the Arabidopsis DAG1 protein requires the DELLA protein GAI to repress the GA biosynthetic gene GA3ox1 during maturation, dormancy and germination of seeds [75]. RGL2 (RGA LIKE2), GAI (GA INSENSITIVE).

DAG1 cooperates with GAI to negatively regulate GA3ox1. Indeed, GAI is necessary for the binding of DAG1 to the DOF sites in the GA3ox1 promoter, and it directly interacts with DAG1 [75]. The cooperation between DAG1 and GAI is further strengthened by the reciprocal control of these two factors, which mutually effect their expression [75] (Figure 1).

GAI has long been believed to have overlapping functions with the other DELLA protein RGA in negatively controlling seed germination and other plant processes $[67,69,76]$. However, more recently, it was shown that RGA and GAI have distinct roles in this process, since rga28 mutant seeds have been demonstrated to be more sensitive to stratification, a phenotype probably due to an increased dormancy, thus suggesting that RGA, but not GAI, promotes seed dormancy [77]. In addition, a transcriptomic analysis showed that GAI, but not RGA, is upregulated by DAG1 inactivation [78], consistently with the reciprocal transcriptional control of DAG1 and GAI during seed germination [75].

Interestingly DAG2, the DOF protein which plays an antagonistic role to DAG1 [72], has been shown to negatively control expression of $R G A$, but not of GAI. Indeed, $R G A$ transcript level is significantly increased in dag2 mutant seeds exposed to Red light, consistently with the function of DAG2 as a positive regulator of seed germination in the PIF1-DAG1 molecular pathway [79].

\section{DOF Proteins in Seedling Development and Other Light-Mediated Processes}

Seedling development depends on environmental conditions. Indeed, once germination is completed, seedlings undergo two possible developmental programs, photomorphogenesis or skotomorphogenesis, depending on the presence or absence of light, respectively [18]. Photomorphogenesis is characterised by inhibition of hypocotyl elongation, open and expanded cotyledons and chloroplast development, whereas skotomorphogenesis is characterised by long hypocotyls and small unfolded cotyledons. Light, mainly through the photoreceptors phytochrome $\mathrm{A}$ (phyA) and phyB, mediates these developmental programs via downstream signalling molecules, and through the control of hormonal levels. Besides phyA and phyB, the blue/UV-A absorbing cryptochromes (cry) have partially redundant functions in the control of photomorphogenic responses, such as hypocotyl elongation and cotyledon expansion (for a review, see Reference [80]). The PIF bHLH transcription factors are the main downstream signalling factors of the phytochromes. Seedlings of the pifq quadruple mutant lacking PIF1, PIF3, PIF4 and PIF5 display a constitutive photomorphogenic 
phenotype when grown in the dark, thus suggesting that these PIF factors redundantly promote skotomorphogenesis [81-83]. This action is counteracted by DELLA proteins, which inhibit PIF activity or promote degradation of PIF factors [84], thus promoting photomorphogenesis. Gas, in turn, promote degradation of DELLA proteins, therefore leading to stabilisation of PIF proteins [57,58]. Indeed, GAs promote etiolated growth and repress photomorphogenesis in the dark [85].

GA metabolism is controlled by light during seedling development, as light induces the expression of the GA catabolic genes in seedlings, thus lowering GA level [86]. GAs and light, which antagonistically control photomorphogenesis, both converge on PIF proteins.

COG1 (COGWHEEL 1) is the first DOF protein which was shown to be involved in both phyAand phyB-mediated seedling development. The $\operatorname{cog} 1-D$ dominant mutant overexpressing COG1, shows attenuated light-mediated responses, namely light-mediated inhibition of hypocotyl elongation, cotyledon opening, anthocyanin accumulation and light-inducible gene expression [87]. Although COG1 is likely a negative regulator in both phyA and phyB signalling pathways, COG1 expression is induced by both Red and Far Red light, thus suggesting that this DOF factor may be a component of a fine-tuning mechanism in phytochrome signalling [87]. More recently, it has been shown that COG1 promotes hypocotyl elongation, through PIF4 and PIF5, which in turn induce Brassinosteroids (BRs) biosynthesis. Indeed, COG1 directly binds the promoter of PIF4 and PIF5 as revealed by the ChIP assay [88].

COG1 is also involved in seed tolerance to deterioration, the process of loss of vigour and viability: indeed, the dominant allele $\operatorname{cog} 1-2 D$ that overexpresses COG1 displayed increased tolerance to deterioration, a phenotype dependent on a higher GA level and a reduced permeability of the seed coat [89]. This phenotype is in agreement with the negative role of COG1 in light signalling, since Red and Far Red light have a negative role in seed tolerance to deterioration, as indicated by the increased tolerance of the phyB-9 and phyA-211 mutant seeds [89]. In addition, it has recently been demonstrated that COG1 controls the expression of the peroxidases PRX2 and PRX25, which are involved in the polymerisation of suberin in the seed coat [90]. Also, the Arabidopsis DOF protein, AtDOF4.2 (At4g21030), has been proposed to be involved in seed coat composition and mucilage production [91].

The dominant mutant allele $c d f 4-1 D$ also shows increased seed tolerance to deterioration due to overexpression of CDF4 (CYCLING DOF FACTOR 4) [89]. CDF4 belongs to a sub-family of DOF proteins homologous to $C D F 1$, which negatively controls expression of the floral activator-encoding gene $C O$ (CONSTANS) [92]. The CDF1-4 proteins redundantly repress the transcription of $C O$, thus representing key elements of the photoperiodic control of flowering in Arabidopsis. Interestingly, CDF and COG1 belong to the same DOF phylogenetic clade, previously referred to as group II [93].

In addition to being involved in the negative control of clock-dependent photoperiodic flowering response [94,95], it was recently shown that CDF5 promotes cell expansion and hypocotyl elongation in a light- and clock-dependent manner [96]. CDF5 acts downstream of both the PIFs and the PRR9/7/5 (PSEUDO-RESPONSE REGULATORS 9/7/5) antagonistic pathway, which promote and, respectively, inhibit hypocotyl growth. Both PIFs and PRRs target CDF5: PIFs induce pre-dawn expression of CDF5 to promote hypocotyl growth, whereas PRRs directly repress CDF5 from morning to dusk to prevent overgrowth of the hypocotyl [96] (Figure 2). 


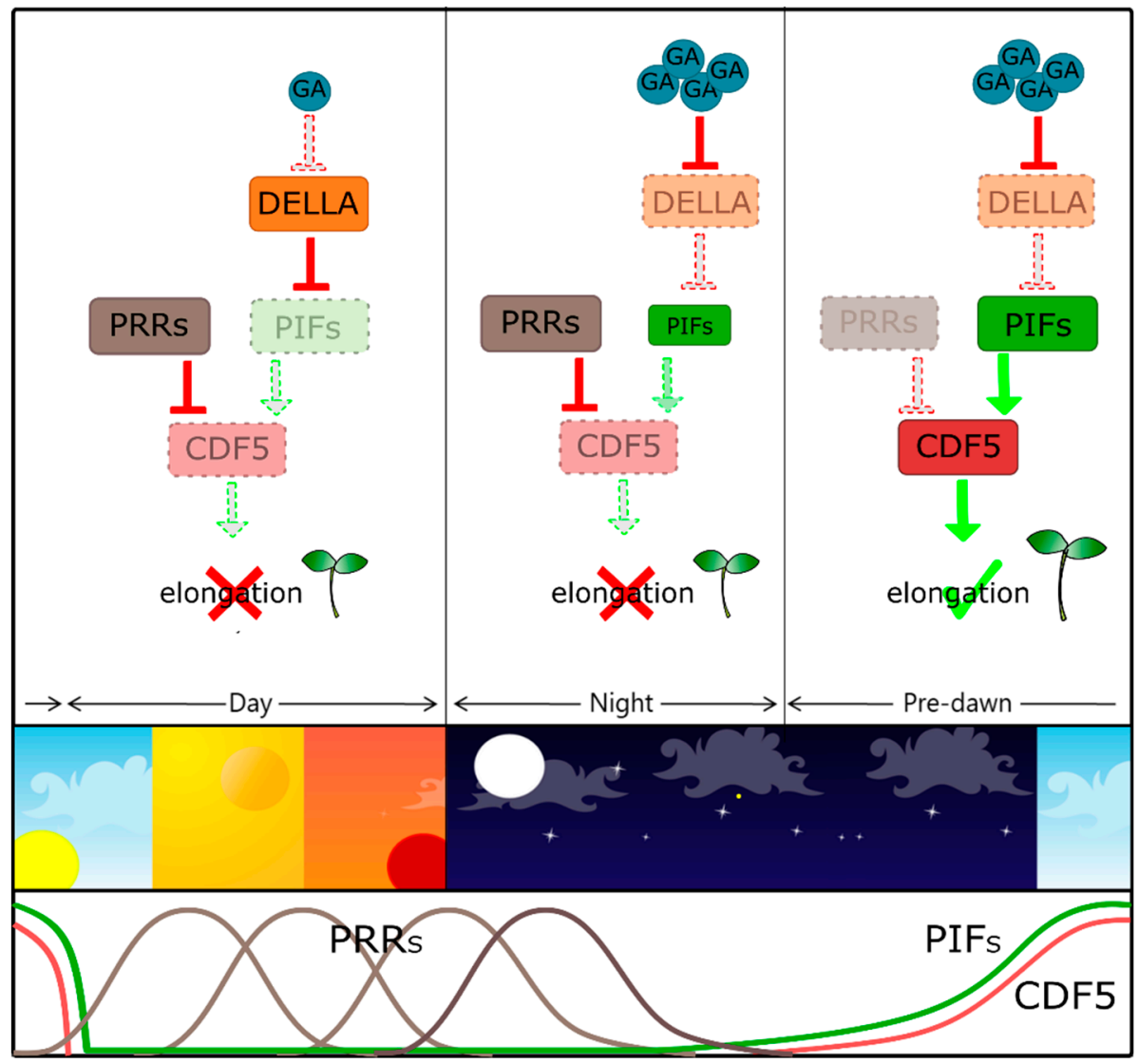

Figure 2. CDF5 promotes hypocotyl elongation in a clock-dependent manner. Expression of CDF5 is antagonistically regulated by both PIFs and PRRs, which directly interact, in order to control hypocotyl elongation during the light/dark cycles. From morning to dusk: accumulation of DELLA proteins, due to the absence of GAs, represses PIFs. PRR proteins (PRRs) directly repress CDF5, leading to inhibition of hypocotyl elongation. During the night: GAs promote DELLA degradation and in turn, stabilisation of PIFs. PRRs inhibit the activity of PIFs in post-dusk phase, gating the hypocotyl elongation to pre-dawn (upper panel). Schematic representation of the PRRs, PIFs and CDF5 proteins temporal activity (lower panel) [96]. CDF5 (CYCLING DOF FACTOR 5), PRRs (PSEUDO-RESPONSE REGULATORS), PIFs (PHYTOCHROME INTERACTING FACTORS).

Similarly, DAG1 has been recently shown to promote cell expansion and hypocotyl elongation [97]: light-grown dag1 mutant seedlings have hypocotyls significantly shorter than the wild-type, suggesting that DAG1 is a negative regulator in the light-mediated inhibition of hypocotyl elongation [73]. Through a genome-wide analysis, it was shown that DAG1 promotes hypocotyl elongation through the control of ABA, ethylene and auxin signalling. Indeed, Gene Ontology analysis of the $257 \mathrm{DE}$ (Differentially Expressed) genes in dag1 hypocotyls compared to the wild-type, revealed that "response to abscisic acid", "ethylene biosynthetic process" as well as "response to ethylene" and "response to auxin" were among the most significantly enriched categories [97]. Consistently, DAG1 directly binds to the promoters of WRKY18 that encodes a transcription factor involved in ABA signalling, of the ethylene-induced gene, ERF2 (ETHYLENE RESPONSE FACTOR 2), and of the SAUR67 (SMALL AUXIN UP RNA 67), an auxin-responding gene encoding a protein promoting hypocotyl cell expansion [97].

The Arabidopsis DOF protein, OBP3 (OBF4 BINDING PROTEIN 3), has also been shown to be involved in light-dependent inhibition of hypocotyl elongation. Indeed, overexpression of $O B P 3$ in the activation-tagged line sob1-D (suppressor of phyB-4 dominant) reverted the long hypocotyl phenotype of the phyB-4 mutant [98], suggesting that OBP3 promotes phyB-mediated inhibition of hypocotyl elongation. Interestingly, reduced OBP3 expression in the OBP3-RNAi lines displayed larger 
cotyledons, mainly under blue light, indicating that OBP3 acts downstream of both the phyB and cry1 photoreceptors, to repress cell expansion [98].

\section{DOF in Early Steps of Arabidopsis Development}

Arabidopsis DOF genes are mainly expressed in the vascular system, in the xylem, in the phloem or both (for a review, see Reference [99]). Comparison of transcriptional and translational profiles suggested that DAG1 and ITD1 (INTERCELLULAR TRAFFICKING DOF1) were possibly capable of moving from the tissue where they were expressed (phloem) to the neighbouring tissue (pericycle), and function as non-cell autonomous (NCA) transcription factors [100]. Experimental evidence of the plasmodesmata-dependent movement from the root stele to the endodermis has been subsequently provided for ITD1 by Chen and co-authors [101]. These authors also identified the intercellular trafficking motif (ITM) that is responsible for selective cell-to-cell movement and encompasses the DOF domain and one element of the bipartite NLS (Nuclear Localisation Signal) [101].

More recently, two Arabidopsis DOF proteins (DOF2.4 and DOF5.1) have been identified as mobile factors involved in root procambial development and were named PEAR1 and 2 (PHLOEM EARLY DOF1 and 2). The corresponding PEAR1 and 2 genes are highly expressed in protophloem sieve elements (PSE) [102]. PEAR1 and 2 were shown to trigger periclinal cell division by controlling genes that promote radial growth, such as SUPPRESSOR OF MAX2 1-LIKE3 (SMXL3), encoding a key regulator of phloem formation [103]. In addition, four homologues (DOF3.2, DOF5.3, DOF1.1 and DOF5.6 (Table 2), have been identified as PSE-specifically or PSE-abundantly expressed DOF genes with a broader protein localisation. These DOF factors redundantly function in the promotion of periclinal cell divisions in PSE cells [102]. The action of PEAR factors is counteracted by the HD-ZIP III transcription factors PHB, CNA and REV (PHABULOSA, CORONA and REVOLUTA). In addition, this molecular network involves a double-negative feedback loop where PEAR1 induces transcription of the PHB, CNA, and REV genes and the corresponding PHB, CNA and REV proteins negatively control PEAR1 transcription and protein movement [102].

Table 2. Arabidopsis DOF genes encoding PHLOEM EARLY DOF (PEAR) proteins.

\begin{tabular}{cccc}
\hline Name & Gene ID & Synonymous & References \\
\hline PEAR1 & AT2G37590 & AtDof2.4 & {$[102]$} \\
PEAR2 & AT5G02460 & AtDof5.1 & {$[102,104]$} \\
DOF6 & AT3G45610 & AtDof3.2 & {$[65,102]$} \\
OBP2 & AT1G07640 & AtDof1.1 & {$[102,105]$} \\
TMO6 & AT5G60200 & AtDof5.3 & {$[102,106]$} \\
HCA2 & AT5G62940 & AtDof5.6 & {$[102,107]$} \\
\hline
\end{tabular}

In the table are reported the two PEAR proteins identified as mobile factors in root Protophloem Sieve Elements (PSE) and the four homologues identified as PSE-specifically or PSE-abundantly expressed DOF genes. OBP2 (ocs Binding Factor/OBF BINDING PROTEIN2), TMO6 (TARGET OF MONOPTEROS 6, HCA2 (HIGH CAMBIAL ACTIVITY2).

The transition from seeds' dormancy to germination involves a wide reprogramming of the transcriptome and involves chromatin remodelling. The PRC2 (Polycomb Repressive Complex 2), which is responsible for the repressive mark H3K27me3, has been shown to target several master regulators of this transition [108,109]. Indeed, PRC2 is required to switch off these seed-specific genes to allow seedling growth [108]. Consistently, fie (fertilization independent endosperm) mutant seeds, lacking a functional PRC2, displayed dormancy and germination defects [108]. Genome-wide analysis of the chromatin state of wild-type and fie seedlings revealed a number of DOF genes (Table 3) as putative targets of PRC2 [108]. Further studies on one of these, DAG1, showed that in developing seedlings, its transcribed region is significantly enriched in the H3K27me3 repressive mark [74]. Interestingly, among the DOF genes marked by H3K27me3, PEAR genes were also found, consistent with their master role during vascular development and root radial growth. 
Table 3. Arabidopsis DOF genes marked by H3K27me3.

\begin{tabular}{cccc}
\hline Name & Gene ID & Synonymous [82] & References \\
\hline DOF6 & AT3G45610 & AtDOF3.2 & {$[65,102]$} \\
DAG1 & AT3G61850 & AtDOF3.7 & {$[71,73,74]$} \\
DAG2 & AT2G46590 & AtDOF2.5 & {$[72,79]$} \\
ITD1 & AT4G00940 & AtDOF4.1 & {$[101]$} \\
PEAR1 & AT2G37590 & AtDOF2.4 & {$[102]$} \\
PEAR2 & AT5G02460 & AtDOF5.1 & {$[102,104]$} \\
TMO6 & AT5G60200 & AtDOF5.3 & {$[102,106]$} \\
OBP2 & AT1G07640 & AtDOF1.1 & {$[102,105]$} \\
HCA2 & AT5G62940 & AtDOF5.6 & {$[102,107]$} \\
CDF6 & AT1G26790 & AtDOF1.3 & {$[98,112]$} \\
OBP3 & AT3G55370 & AtDOF3.6 & {$[113]$} \\
SCAP1 & AT5G65590 & AtDOF5.7 & {$[114]$} \\
& AT1G28310 & AtDOF1.4 & \\
& AT2G28510 & AtDOF2.1 & {$[91,105]$} \\
& AT2G28810 & AtDOF2.2 & {$[91]$} \\
& AT3G52440 & AtDOF3.5 & {$[91]$} \\
& AT4G21030 & AtDOF4.2 & {$[116]$} \\
\hline
\end{tabular}

DOF genes that are enriched in the H3K27me3 epigenetic mark. Data from Bouyer et al. [108]. DAG1, DAG2 (DOF AFFECTING GERMINATION1, 2), ITD1 (INTERCELLULAR TRAFFICKING DOF1), SCAP1 (STOMATAL CARPENTER 1).

\section{Conclusions}

DOF proteins are plant-specific transcription factors present in the whole plant kingdom, including the green unicellular alga Chlamydomonas reinhardtii (1 DOF gene), the moss Physcomitrella patens (19 DOF genes) and the model plant Arabidopsis thaliana (36 DOF genes) [117,118]. Phylogenetic analysis suggested that $D O F$ genes originated from a common ancestor (conserved as a single copy in Chlamydomonas) that underwent structural and functional diversification through several rounds of gene duplications [117]. This evolutionary process may be linked with the development of new specific functions required to cope with increasingly complex plant developmental regulatory networks. As a result, DOF factors are involved in diverse plant developmental processes, including seed dormancy, germination and photomorphogenesis. The recent evidence that a number of Arabidopsis DOF factors play a key role in the promotion of radial growth in the procambial tissues of the root apical meristem [102], further emphasises the importance of this gene family in plant life.

Author Contributions: Writing, P.V. and P.C.; original draft preparation, V.R., C.L., V.D.A., A.L. and S.O. All authors reviewed, edited and discussed this review. All authors have read and agreed to this version of the manuscript.

Funding: This research received no external funding.

Acknowledgments: We thank Roberto Mattioli for constructive suggestions on this work, and Lorenza Palazzoni and Luca Quattrocchi for their helpful technical assistance.

Conflicts of Interest: The authors declare no conflict of interest.

\section{References}

1. Yanagisawa, S. A novel DNA-binding domain that may form a single zinc finger motif. Nucleic Acids Res. 1995, 23, 3403-3410. [CrossRef] [PubMed]

2. Zhang, B.; Chen, W.; Foley, R.C.; Buttner, M.; Singh, K.B. Interactions between Distinct Types of DNA Binding Proteins Enhance Binding to ocs Element Promoter Sequences. Plant Cell 1995, 7, 2241-2252. 
3. De Paolis, A.; Sabatini, S.; De Pascalis, L.; Costantino, P.; Capone, I. A rolB regulatory factor belongs to a new class of single zinc finger plant proteins. Plant J. 1996, 10, 215-223. [CrossRef] [PubMed]

4. Yanagisawa, S.; Izui, K. Molecular cloning of two DNA-binding proteins of maize that are structurally different but interact with the same sequence motif. J. Biol. Chem. 1993, 268, 16028-16036. [PubMed]

5. Capone, I.; Cardarelli, M.; Mariotti, D.; Pomponi, M.; De Paolis, A.; Costantino, P. Different promoter regions control level and tissue specificity of expression of Agrobacterium rhizogenes rolB gene in plants. Plant Mol. Biol. 1991, 16, 427-436. [CrossRef] [PubMed]

6. Capone, I.; Frugis, G.; Costantino, P.; Cardarelli, M. Expression in different populations of cells of the root meristem is controlled by different domains of the rolB promoter. Plant Mol. Biol. 1994, 25, 681-691. [CrossRef]

7. Yanagisawa, S.; Schmidt, R.J. Diversity and similarity among recognition sequences of Dof transcription factors. Plant J. 1999, 17, 209-214. [CrossRef]

8. Noguero, M.; Atif, R.M.; Ochatt, S.; Thompson, R.D. The role of the DNA-binding One Zinc Finger (DOF) transcription factor family in plants. Plant Sci. 2013, 209, 32-45. [CrossRef]

9. Gupta, S.; Malviya, N.; Kushwaha, H.; Nasim, J.; Bisht, N.C.; Singh, V.K.; Yadav, D. Insights into structural and functional diversity of Dof (DNA binding with one finger) transcription factor. Planta 2015, 241, 549-562. [CrossRef]

10. Yanagisawa, S. Structure, Function, and Evolution of the Dof Transcription Factor Family. Plant Transcr. Factors 2016, 183-197.

11. West, M.A.L.; Harada, J.J. Embryogenesis in higher plants: An overview. Plant Cell 1993, 5, 1361. [CrossRef] [PubMed]

12. Koornneef, M.; Karssen, C.M. Seed Dormancy and Germination. In Arabidopsis; Meyerowitz, E.M., Somerville, C.R., Eds.; Cold Spring Harbor Laboratory Press: New York, NY, USA, 1994; pp. 313-334.

13. Koornneef, M.; Bentsink, L.; Hilhorst, H. Seed dormancy and germination. Curr. Opin. Plant Biol. 2002, 5, 33-36. [CrossRef]

14. Shinomura, T.; Nagatani, A.; Chory, J.; Furuya, M. The induction of seed germination in Arabidopsis thaliana is regulated principally by phytochrome B and secondarily by phytochrome A. Plant Physiol. 1994, 104, 363-371. [CrossRef]

15. Toyomasu, T.; Kawaide, H.; Mitsuhashi, W.; Inoue, Y.; Kamiya, Y. Phytochrome regulates gibberellin biosynthesis during germination of photoblastic lettuce seeds. Plant Physiol. 1998, 118, 1517-1523. [CrossRef]

16. Yamaguchi, S.; Smith, M.W.; Brown, R.G.S.; Kamiya, Y.; Sun, T. Phytochrome Regulation and Differential Expression of Gibberellin 3b-Hydroxylase Genes in Germinating Arabidopsis Seeds. Plant Cell 1998, 10, 2115-2126. [CrossRef]

17. Seo, M.; Hanada, A.; Kuwahara, A.; Endo, A.; Okamoto, M.; Yamauchi, Y.; North, H.; Marion-Poll, A.; Sun, T.; Koshiba, T.; et al. Regulation of hormone metabolism in Arabidopsis seeds: Phytochrome regulation of abscisic acid metabolism and abscisic acid regulation of gibberellin metabolism. Plant J. 2006, 48, 354-366. [CrossRef]

18. Casal, J.J.; Luccioni, L.G.; Oliverio, K.A.; Boccalandro, H.E. Light, phytochrome signalling and photomorphogenesis in Arabidopsis. Photochem. Photobiol. Sci. 2003, 2, 625-636. [CrossRef]

19. Forde, B.G.; Heyworth, A.; Pywell, J.; Kreis, M. Nucleotide sequence of a B1 hordein gene and the identification of possible upstream regulatory elements in endosperm storage protein genes from barley, wheat and maize. Nucleic Acids Res. 1985, 13, 7327-7339. [CrossRef]

20. Kreis, M.; Forde, B.G.; Rahman, S.; Miflin, B.J.; Shewry, P.R. Molecular evolution of the seed storage proteins of barley, rye and wheat. J. Mol. Biol. 1985, 183, 499-502. [CrossRef]

21. Hill, D.E.; Hope, I.A.; Macke, J.P.; Struhl, K. Saturation mutagenesis of the yeast bis3 regulatory site: Requirements for transcriptional induction and for binding by GCN4 activator protein. Science 1986, 234, 451-457. [CrossRef] [PubMed]

22. Boronat, A.; Martínez, M.C.; Reina, M.; Puigdomènech, P.; Palau, J. Isolation and sequencing of a 28 kD glutelin-2 gene from maize. common elements in the $5^{\prime}$ flanking regions among zein and glutelin genes. Plant Sci. 1986, 47, 95-102. [CrossRef]

23. Thompson, G.A.; Larkins, B.A. Structural elements regulating zein gene expression. BioEssays 1989, 10, 108-113. [CrossRef] [PubMed] 
24. Ottoboni, L.M.M.; Leite, A.; Yunes, J.A.; Targon, M.L.P.N.; de Souza Filho, G.A.; Arruda, P. Sequence analysis of $22 \mathrm{kDa}$-like $\alpha$-coixin genes and their comparison with homologous zein and kafirin genes reveals highly conserved protein structure and regulatory elements. Plant Mol. Biol. 1993, 21, 765-778. [CrossRef] [PubMed]

25. Maier, U.-G.; Brown, J.W.S.; Toloczyki, C.; Feix, G. Binding of a nuclear factor to a consensus sequence in the $5^{\prime}$ flanking region of zein genes from maize. EMBO J. 1987, 6, 17-22. [CrossRef] [PubMed]

26. Hammond-Kosack, M.C.; Holdsworth, M.J.; Bevan, M.W. In vivo footprinting of a low molecular weight glutenin gene (LMWG-1D1) in wheat endosperm. EMBO J. 1993, 12, 545-554. [CrossRef] [PubMed]

27. Ueda, T.; Wang, Z.; Pham, N.; Messing, J. Identification of a transcriptional activator-binding element in the 27-kilodalton zein promoter, the -300 element. Mol. Cell. Biol. 1994, 14, 4350-4359. [CrossRef]

28. Wang, Z.; Ueda, T.; Messing, J. Characterization of the maize prolamin box-binding factor-1 (PBF-1) and its role in the developmental regulation of the zein multigene family. Gene 1998, 223, 321-332. [CrossRef]

29. Vicente-Carbajosa, J.; Moose, S.P.; Parsons, R.L.; Schmidt, R.J. A maize zinc-finger protein binds the prolamin box in zein gene promoters and interacts with the basic leucine zipper transcriptional activator Opaque2. Proc. Natl. Acad. Sci. USA 1997, 94, 7685-7690. [CrossRef]

30. Mena, M.; Vicente-Carbajosa, J.; Schmidt, R.J.; Carbonero, P. An endosperm-specific DOF protein from barley, highly conserved in wheat, binds to and activates transcription from the prolamin-box of a native B-hordein promoter in barley endosperm. Plant J. 1998, 16, 53-62. [CrossRef]

31. Albani, D.; Hammond-Kosack, M.C.U.; Smith, C.; Conlan, S.; Colot, V.; Holdsworth, M.; Bevan, M.W. The wheat transcriptional activator SPA: A seed-specific bZIP protein that recognizes the GCN4-like motif in the bifactorial endosperm box of prolamin genes. Plant Cell 1997, 9, 171-184. [PubMed]

32. Vicente-Carbajosa, J.; Oñate, L.; Lara, P.; Diaz, I.; Carbonero, P. Barley BLZ: A bZIP transcriptional activator that interacts with endosperm-specific gene promoters. Plant J. 1998, 13, 629-640. [PubMed]

33. Wu, C.Y.; Suzuki, A.; Washida, H.; Takaiwa, F. The GCN4 motif in a rice glutelin gene is essential for endosperm-specific gene expression and is activated by opaque-2 in transgenic rice plants. Plant J. 1998, 14, 673-783. [CrossRef] [PubMed]

34. Oñate, L.; Vicente-Carbajosa, J.; Lara, P.; Díaz, I.; Carbonero, P. Barley BLZ2, a seed-specific bZIP protein that interacts with BLZ1 in vivo and activates transcription from the GCN4-like motif of B-hordein promoters in barley endosperm. J. Biol. Chem. 1999, 274, 9175-9182. [CrossRef] [PubMed]

35. Schmidt, R.J.; Burr, F.A.; Aukerman, M.J.; Burr, B. Maize regulatory gene opaque-2 encodes a protein with a "leucine-zipper" motif that binds to zein DNA. Proc. Natl. Acad. Sci. USA 1990, 87, 46-50. [CrossRef] [PubMed]

36. Schmidt, R.J.; Ketudat, M.; Aukerman, M.J.; Hoschek, G. Opaque-2 is a transcriptional activator that recognizes a specific target site in 22-kD zein genes. Plant Cell 1992, 4, 689-700. [PubMed]

37. Yamamoto, M.P.; Onodera, Y.; Touno, S.M.; Takaiwa, F. Synergism between RPBF Dof and RISBZ1 bZIP activators in the regulation of rice seed expression genes. Plant Physiol. 2006, 141, 1694-1707. [CrossRef]

38. Diaz, I.; Vicente-Carbajosa, J.; Abraham, Z.; Martínez, M.; LaMoneda, I.I.; Carbonero, P. The GAMYP protein from barley interacts with the DOF transcription factor BPBF and activates endosperm-specific genes during seed development. Plant J. 2002, 29, 453-464. [CrossRef]

39. Diaz, I.; Martinez, M.; Isabel-LaMoneda, I.; Rubio-Somoza, I.; Carbonero, P. The DOF protein, SAD, interacts with GAMYB in plant nuclei and activates transcription of endosperm-specific genes during barley seed development. Plant J. 2005, 42, 652-662. [CrossRef]

40. Wu, J.; Chen, L.; Chen, M.; Zhou, W.; Dong, Q.; Jiang, H.; Cheng, B. The DOF-domain transcription factor ZmDOF36 positively regulates starch synthesis in transgenic maize. Front. Plant Sci. 2019, 10, 465. [CrossRef]

41. Qi, X.; Li, S.; Zhu, Y.; Zhao, Q.; Zhu, D.; Yu, J. ZmDof3, a maize endosperm-specific Dof protein gene, regulates starch accumulation and aleurone development in maize endosperm. Plant Mol. Biol. 2017, 93, 7-20. [CrossRef] [PubMed]

42. Wang, H.W.; Zhang, B.; Hao, Y.J.; Huang, J.; Tian, A.G.; Liao, Y.; Zhang, J.S.; Chen, S.Y. The soybean Dof-type transcription factor genes, GmDof4 and GmDof11, enhance lipid content in the seeds of transgenic Arabidopsis plants. Plant J. 2007, 52, 716-729. [CrossRef]

43. Su, Y.; Liang, W.; Liu, Z.; Wang, Y.; Zhao, Y.; Ijaz, B.; Hua, J. Overexpression of GhDof1 improved salt and cold tolerance and seed oil content in Gossypium hirsutum. J. Plant Physiol. 2017, 218, 222-234. [CrossRef] [PubMed] 
44. Fincher, G.B. Molecular and Cellular Biology Associated with Endosperm Mobilization in Germinating Cereal Grains. Annu. Rev. Plant Physiol. Plant Mol. Biol. 1989, 40, 305-346. [CrossRef]

45. Skadsen, R.W. Physiological and molecular genetic mechanisms regulating hydrolytic enzyme gene expression in cereal grains. Physiol. Plant. 1998, 104, 486-502. [CrossRef]

46. Gubler, F.; Jacobsen, J.V. Gibberellin-responsive elements in the promoter of a barley high-pI $\alpha$-amylase gene. Plant Cell 1992, 4, 1435-1441. [CrossRef]

47. Lanahan, M.B.; Ho, T.H.D.; Rogers, S.W.; Rogers, J.C. A gibberellin response complex in cereal $\alpha$-amylase gene promoters. Plant Cell 1992, 4, 203-211. [CrossRef]

48. Gubler, F.; Kalla, R.; Roberts, J.K.; Jacobsen, J.V. Gibberellin-regulated expression of a myb gene in barley aleurone cells: Evidence for Myb transactivation of a high-pl alpha-amylase gene promoter. Plant Cell 1995, 7, 1879-1891. [CrossRef]

49. Gubler, F.; Raventos, D.; Keys, M.; Watts, R.; Mundy, J.; Jacobsen, J.V. Target genes and regulatory domains of the GAMYB transcriptional activator in cereal aleurone. Plant J. 1999, 1, 1-9. [CrossRef]

50. Mena, M.; Javier Cejudo, F.; Isabel-Lamoneda, I.; Carbonero, P. A role for the DOF transcription factor $\mathrm{BPBF}$ in the regulation of gibberellin-responsive genes in barley aleurone. Plant Physiol. 2002, 130, 111-119. [CrossRef]

51. Isabel-LaMoneda, I.; Diaz, I.; Martinez, M.; Mena, M.; Carbonero, P. SAD: A new DOF protein from barley that activates transcription of a cathepsin B-like thiol protease gene in the aleurone of germinating seeds. Plant J. 2003, 33, 329-340. [CrossRef] [PubMed]

52. Moreno-Risueno, M.Á.; Díaz, I.; Carrillo, L.; Fuentes, R.; Carbonero, P. The HvDOF19 transcription factor mediates the abscisic acid-dependent repression of hydrolase genes in germinating barley aleurone. Plant J. 2007, 51, 352-365. [CrossRef] [PubMed]

53. Silverstone, A.L.; Jung, H.S.; Dill, A.; Kawaide, H.; Kamiya, Y.; Sun, T.P. Repressing a repressor: Gibberellin-induced rapid reduction of the RGA protein in Arabidopsis. Plant Cell 2001, 13, 1555-1566. [CrossRef] [PubMed]

54. Dill, A.; Thomas, S.G.; Hu, J.; Steber, C.M.; Sun, T.P. The arabidopsis F-box protein SLEEPY1 targets gibberellin signaling repressors for gibberellin-induced degradation. Plant Cell 2004, 16, 1392-1405. [CrossRef] [PubMed]

55. McGinnis, K.M.; Thomas, S.G.; Soule, J.D.; Strader, L.C.; Zale, J.M.; Sun, T.P.; Steber, C.M. The Arabidopsis SLEEPY1 gene encodes a putative F-box subunit of an SCF E3 ubiquitin ligase. Plant Cell 2003, 15, 1120-1130. [CrossRef] [PubMed]

56. Daviere, J.M.; de Lucas, M.; Prat, S. Transcriptional factor interaction: A central step in DELLA function. Curr. Opin. Genet. Dev. 2008, 18, 295-303. [CrossRef]

57. De Lucas, M.; Davière, J.M.; Rodríguez-Falcón, M.; Pontin, M.; Iglesias-Pedraz, J.M.; Lorrain, S.; Fankhauser, C.; Blázquez, M.A.; Titarenko, E.; Prat, S. A molecular framework for light and gibberellin control of cell elongation. Nature 2008, 451, 480-484. [CrossRef]

58. Feng, S.; Martinez, C.; Gusmaroli, G.; Wang, Y.; Zhou, J.; Wang, F.; Chen, L.; Yu, L.; Iglesias-Pedraz, J.M.; Kircher, S.; et al. Coordinated regulation of Arabidopsis thaliana development by light and gibberellins. Nature 2008, 451, 475-479. [CrossRef]

59. Richter, R.; Behringer, C.; Müller, I.K.; Schwechheimer, C. The GATA-type transcription factors GNC and GNL/CGA1 repress gibberellin signaling downstream from DELLA proteins and phytochrome-interacting factors. Genes Dev. 2010, 24, 2093-2104. [CrossRef]

60. Yoshida, H.; Ueguchi-Tanaka, M. DELLA and SCL3 balance gibberellin feedback regulation by utilizing INDETERMINATE DOMAIN proteins as transcriptional scaffolds. Plant Signal. Behav. 2014, 9, e20726. [CrossRef]

61. Lee, S.; Cheng, H.; King, K.E.; Wang, W.; He, Y.; Hussain, A.; Lo, J.; Harberd, N.P.; Peng, J. Gibberellin regulates Arabidopsis seed germination via RGL2, a GAI/RGA-like gene whose expression is up-regulated following imbibition. Genes Dev. 2002, 16, 646-658. [CrossRef] [PubMed]

62. Piskurewicz, U.; Jikumaru, Y.; Kinoshita, N.; Nambara, E.; Kamiya, Y.; Lopez-Molina, L. The gibberellic acid signaling repressor RGL2 inhibits Arabidopsis seed germination by stimulating abscisic acid synthesis and ABI5 activity. Plant Cell 2008, 20, 2729-2745. [CrossRef] [PubMed]

63. Stamm, P.; Ravindran, P.; Mohanty, B.; Tan, E.L.; Yu, H.; Kumar, P.P. Insights into the molecular mechanism of RGL2-mediated inhibition of seed germination in Arabidopsis thaliana. BMC Plant Biol. 2012, 12, 179. [CrossRef] 
64. Ravindran, P.; Verma, V.; Stamm, P.; Kumar, P.P. A Novel RGL2-DOF6 Complex Contributes to Primary Seed Dormancy in Arabidopsis thaliana by Regulating a GATA Transcription Factor. Mol. Plant 2017, 10, 1307-1320. [CrossRef] [PubMed]

65. Romero, P.R.; Sicilia, C.B.; Cadenas, A.G.; Zalduegui, P.C.; Sanchez, L.O. Arabidopsis thaliana DOF6 negatively affects germination in non-after ripened seeds and interacts with TCP14. J. Exp. Bot. 2011, 63, 1937-1949. [CrossRef] [PubMed]

66. Resentini, F.; Felipo-Benavent, A.; Colombo, L.; Blázquez, M.A.; Alabadí, D.; Masiero, S. TCP14 and TCP15 mediate the promotion of seed germination by gibberellins in arabidopsis thaliana. Mol. Plant 2015, 8 , 482-485. [CrossRef]

67. Dill, A.; Sun, T.P. Synergistic derepression of gibberellin signaling by removing RGA and GAI function in Arabidopsis thaliana. Genetics 2001, 159, 777-785.

68. Cao, D.; Hussain, A.; Cheng, H.; Peng, J. Loss of function of four DELLA genes leads to light- and gibberellin-independent seed germination in Arabidopsis. Planta 2005, 223, 105-113. [CrossRef]

69. Oh, E.; Yamaguchi, S.; Hu, J.; Yusuke, J.; Jung, B.; Paik, I.; Lee, H.S.; Sun, T.P.; Kamiya, Y.; Choi, G. PIL5, a phytochrome-interacting bHLH protein, regulates gibberellin responsiveness by binding directly to the GAI and RGA promoters in Arabidopsis seeds. Plant Cell 2007, 19, 1192-1208. [CrossRef]

70. Oh, E.; Yamaguchi, S.; Kamiya, Y.; Bae, G.; Chung, W.I.; Choi, G. Light activates the degradation of PIL5 protein to promote seed germination through gibberellin in Arabidopsis. Plant J. 2006, 47, 124-139. [CrossRef]

71. Papi, M.; Sabatini, S.; Bouchez, D.; Camilleri, C.; Costantino, P.; Vittorioso, P. Identification and disruption of an Arabidopsis zinc finger gene controlling seed germination. Genes Dev. 2000, 14, 28-33. [PubMed]

72. Gualberti, G.; Papi, M.; Bellucci, L.; Ricci, I.; Bouchez, D.; Camilleri, C.; Costantino, P.; Vittorioso, P. Mutations in the Dof zinc finger genes DAG2 and DAG1 influence with opposite effects the germination of Arabidopsis seeds. Plant Cell 2002, 14, 1253-1263. [CrossRef] [PubMed]

73. Gabriele, S.; Rizza, A.; Martone, J.; Circelli, P.; Costantino, P.; Vittorioso, P. The Dof protein DAG1 mediates PIL5 activity on seed germination by negatively regulating GA biosynthetic gene AtGA3ox1. Plant J. 2010, 61, 312-323. [CrossRef] [PubMed]

74. Boccaccini, A.; Lorrai, R.; Ruta, V.; Frey, A.; Mercey-Boutet, S.; Marion-Poll, A.; Tarkowska, D.; Strnad, M.; Costantino, P.; Vittorioso, P. The DAG1 transcription factor negatively regulates the seed-to-seedling transition in Arabidopsis acting on ABA and GA levels. BMC Plant Biol. 2016, 16, 198. [CrossRef]

75. Boccaccini, A.; Santopolo, S.; Capauto, D.; Lorrai, R.; Minutello, E.; Serino, G.; Costantino, P.; Vittorioso, P. The DOF protein DAG1 and the DELLA protein GAI cooperate in negatively regulating the AtGA3ox1 gene. Mol. Plant 2014, 7, 1486-1489. [CrossRef]

76. King, K.E.; Moritz, T.; Harberd, N.P. Gibberellins are not required for normal stem growth in Arabidopsis thaliana in the absence of GAI and RGA. Genetics 2001, 159, 767-776.

77. Boccaccini, A.; Santopolo, S.; Capauto, D.; Lorrai, R.; Minutello, E.; Belcram, K.; Palauqui, J.C.; Costantino, P.; Vittorioso, P. Independent and interactive effects of DOF affecting germination 1 (DAG1) and the Della proteins GA insensitive (GAI) and Repressor of ga1-3 (RGA) in embryo development and seed germination. BMC Plant Biol. 2014, 14, 200. [CrossRef]

78. Rizza, A.; Boccaccini, A.; Lopez-Vidriero, I.; Costantino, P.; Vittorioso, P. Inactivation of the ELIP1 and ELIP2 genes affects Arabidopsis seed germination. New Phytol. 2011, 190, 896-905. [CrossRef]

79. Santopolo, S.; Boccaccini, A.; Lorrai, R.; Ruta, V.; Capauto, D.; Minutello, E.; Serino, G.; Costantino, P.; Vittorioso, P. DOF AFFECTING GERMINATION 2 is a positive regulator of light-mediated seed germination and is repressed by DOF AFFECTING GERMINATION 1. BMC Plant Biol. 2015, 15, 72. [CrossRef]

80. Neff, M.M.; Fankhauser, C.; Chory, J. Light: An indicator of time and place. Genes Dev. 2000, 14, $257-271$.

81. Leivar, P.; Tepperman, J.M.; Monte, E.; Calderon, R.H.; Liu, T.L.; Quail, P.H. Definition of early transcriptional circuitry involved in light-induced reversal of PIF-imposed repression of photomorphogenesis in young Arabidopsis seedlings. Plant Cell 2009, 21, 3535-3553. [CrossRef] [PubMed]

82. Leivar, P.; Quail, P.H. PIFs: Pivotal components in a cellular signaling hub Phytochrome signal perception and transduction. Trends Plant 2011, 16, 19-28. [CrossRef] [PubMed]

83. Zhang, Y.; Mayba, O.; Pfeiffer, A.; Shi, H.; Tepperman, J.M.; Speed, T.P.; Quail, P.H. A Quartet of PIF bHLH Factors Provides a Transcriptionally Centered Signaling Hub That Regulates Seedling Morphogenesis through Differential Expression-Patterning of Shared Target Genes in Arabidopsis. PLoS Genet. 2013, 9, e1003244. [CrossRef] [PubMed] 
84. Li, K.; Yu, R.; Fan, L.M.; Wei, N.; Chen, H.; Deng, X.W. DELLA-mediated PIF degradation contributes to coordination of light and gibberellin signalling in Arabidopsis. Nat. Commun. 2016, 7, 11868. [CrossRef] [PubMed]

85. Alabadí, D.; Gil, J.; Blázquez, M.A.; García-Martínez, J.L. Gibberellins repress photomorphogenesis in darkness. Plant Physiol. 2004, 134, 1050-1057. [CrossRef] [PubMed]

86. Achard, P.; Liao, L.; Jiang, C.; Desnos, T.; Bartlett, J.; Fu, X.; Harberd, N.P. DELLAs contribute to plant photomorphogenesis. Plant Physiol. 2007, 143, 1163-1172. [CrossRef]

87. Park, D.H.; Lim, P.O.; Kim, J.S.; Cho, D.S.; Hong, S.H.; Nam, H.G. The Arabidopsis COG1 gene encodes a Dof domain transcription factor and negatively regulates phytochrome signaling. Plant J. 2003, 34, 161-171. [CrossRef]

88. Wei, Z.; Yuan, T.; Tarkowská, D.; Kim, J.; Nam, H.G.; Novák, O.; He, K.; Gou, X.; Li, J. Brassinosteroid biosynthesis is modulated via a transcription factor cascade of COG1, PIF4, and PIF5. Plant Physiol. 2017, 174, 1260-1273. [CrossRef]

89. Bueso, E.; Muñoz-Bertomeu, J.; Campos, F.; Martínez, C.; Tello, C.; Martínez-Almonacid, I.; Ballester, P.; Simón-Moya, M.; Brunaud, V.; Yenush, L.; et al. Arabidopsis COGWHEEL1 links light perception and gibberellins with seed tolerance to deterioration. Plant J. 2016, 87, 583-596. [CrossRef]

90. Renard, J.; Martínez-Almonacid, I.; Sonntag, A.; Molina, I.; Moya-Cuevas, J.; Bissoli, G.; Muñoz-Bertomeu, J.; Faus, I.; Niñoles, R.; Shigeto, J.; et al. PRX2 and PRX25, peroxidases regulated by COG1, are involved in seed longevity in Arabidopsis. Plant Cell Environ. 2020, 43, 315-326. [CrossRef]

91. Zou, H.F.; Zhang, Y.Q.; Wei, W.; Chen, H.W.; Song, Q.X.; Liu, Y.F.; Zhao, M.Y.; Wang, F.; Zhang, B.C.; Lin, Q.; et al. The transcription factor AtDOF4.2 regulates shoot branching and seed coat formation in Arabidopsis. Biochem. J. 2013, 449, 373-388. [CrossRef] [PubMed]

92. Imaizumi, T.; Schultz, T.F.; Harmon, F.G.; Ho, L.A.; Kay, S.A. Plant science: FKF1 F-box protein mediates cyclic degradation of a repressor of CONSTANS in Arabidopsis. Science 2005, 309, 293-297. [CrossRef] [PubMed]

93. Yanagisawa, S. The Dof family of plant transcription factors. Trends Plant Sci. 2002, 7, 555-560. [CrossRef]

94. Fornara, F.; Panigrahi, K.C.S.; Gissot, L.; Sauerbrunn, N.; Rühl, M.; Jarillo, J.A.; Coupland, G. Arabidopsis DOF Transcription Factors Act Redundantly to Reduce CONSTANS Expression and Are Essential for a Photoperiodic Flowering Response. Dev. Cell 2009, 17, 75-86. [CrossRef]

95. Henriques, R.; Wang, H.; Liu, J.; Boix, M.; Huang, L.F.; Chua, N.H. The antiphasic regulatory module comprising CDF5 and its antisense RNA FLORE links the circadian clock to photoperiodic flowering. New Phytol. 2017, 216, 854-867. [CrossRef]

96. Martín, G.; Rovira, A.; Veciana, N.; Soy, J.; Toledo-Ortiz, G.; Gommers, C.M.M.; Boix, M.; Henriques, R.; Minguet, E.G.; Alabadí, D.; et al. Circadian Waves of Transcriptional Repression Shape PIF-Regulated Photoperiod-Responsive Growth in Arabidopsis. Curr. Biol. 2018, 28, 311-318.e5. [CrossRef]

97. Lorrai, R.; Gandolfi, F.; Boccaccini, A.; Ruta, V.; Possenti, M.; Tramontano, A.; Costantino, P.; Lepore, R.; Vittorioso, P. Genome-wide RNA-seq analysis indicates that the DAG1 transcription factor promotes hypocotyl elongation acting on ABA, ethylene and auxin signaling. Sci. Rep. 2018, 8, 15895. [CrossRef]

98. Ward, J.M.; Cufr, C.A.; Denzel, M.A.; Neff, M.M. The dof transcription factor OBP3 modulates phytochrome and cryptochrome signaling in arabidopsis. Plant Cell 2005, 17, 475-485. [CrossRef]

99. Le Hir, R.; Bellini, C. The plant-specific Dof transcription factors family: New players involved in vascular system development and functioning in Arabidopsis. Front. Plant Sci. 2013, 4, 164. [CrossRef]

100. Lee, J.Y.; Colinas, J.; Wang, J.Y.; Mace, D.; Ohler, U.; Benfey, P.N. Transcriptional and posttranscriptional regulation of transcription factor expression in Arabidopsis roots. Proc. Natl. Acad. Sci. USA 2006, 103, 6055-6060. [CrossRef]

101. Chen, H.; Ahmad, M.; Rim, Y.; Lucas, W.J.; Kim, J.Y. Evolutionary and molecular analysis of Dof transcription factors identified a conserved motif for intercellular protein trafficking. New Phytol. 2013, 198, 1250-1260. [CrossRef] [PubMed]

102. Miyashima, S.; Roszak, P.; Sevilem, I.; Toyokura, K.; Blob, B.; Heo, J.-O.; Mellor, N.; Help-Rinta-Rahko, H.; Otero, S.; Smet, W.; et al. Mobile PEAR transcription factors integrate positional cues to prime cambial growth. Nature 2019, 565, 490-494. [CrossRef] 
103. Wallner, E.S.; López-Salmerón, V.; Belevich, I.; Poschet, G.; Jung, I.; Grünwald, K.; Sevilem, I.; Jokitalo, E.; Hell, R.; Helariutta, Y.; et al. Strigolactone- and Karrikin-Independent SMXL Proteins Are Central Regulators of Phloem Formation. Curr. Biol. 2017, 27, 1241-1247. [CrossRef] [PubMed]

104. Kim, H.S.; Kim, S.J.; Abbasi, N.; Bressan, R.A.; Yun, D.J.; Yoo, S.D.; Kwon, S.Y.; Choi, S.B. The DOF transcription factor Dof5.1 influences leaf axial patterning by promoting Revoluta transcription in Arabidopsis. Plant J. 2010, 64, 524-535. [CrossRef] [PubMed]

105. Skirycz, A.; Reichelt, M.; Burow, M.; Birkemeyer, C.; Rolcik, J.; Kopka, J.; Zanor, M.I.; Gershenzon, J.; Strnad, M.; Szopa, J.; et al. DOF transcription factor AtDof1.1 (OBP2) is part of a regulatory network controlling glucosinolate biosynthesis in Arabidopsis. Plant J. 2006, 47, 10-24. [CrossRef] [PubMed]

106. Schlereth, A.; Möller, B.; Liu, W.; Kientz, M.; Flipse, J.; Rademacher, E.H.; Schmid, M.; Jürgens, G.; Weijers, D. MONOPTEROS controls embryonic root initiation by regulating a mobile transcription factor. Nature 2010, 464, 913-916. [CrossRef] [PubMed]

107. Guo, Y.; Qin, G.; Gu, H.; Qu, L.J. Dof5.6/HCA2, a dof transcription factor gene, regulates interfascicular cambium formation and vascular tissue development in Arabidopsis. Plant Cell 2009, 21, 3518-3534. [CrossRef]

108. Bouyer, D.; Roudier, F.; Heese, M.; Andersen, E.D.; Gey, D.; Nowack, M.K.; Goodrich, J.; Renou, J.P.; Grini, P.E.; Colot, V.; et al. Polycomb repressive complex 2 controls the embryo-to-seedling phase transition. PLoS Genet. 2011, 7, e1002014. [CrossRef]

109. Muller, K.; Bouyer, D.; Schnittger, A.; Kermode, A.R. Evolutionarily conserved histone methylation dynamics during seed life-cycle transitions. PLoS ONE 2012, 7, e51532. [CrossRef]

110. Theologis, A.; Ecker, J.R.; Palm, C.J.; Federspiel, N.A.; Kaul, S.; White, O.; Alonso, J.; Altafi, H.; Araujo, R.; Bowman, C.L.; et al. Sequence and analysis of chromosome 1 of the plant Arabidopsis thaliana. Nature 2000, 408, 816-820. [CrossRef]

111. Gaudet, P.; Livstone, M.S.; Lewis, S.E.; Thomas, P.D. Phylogenetic-based propagation of functional annotations within the Gene Ontology consortium. Brief. Bioinform. 2011, 12, 449-462. [CrossRef] [PubMed]

112. Kang, H.G.; Singh, K.B. Characterization of salicylic acid-responsive, Arabidopsis Dof domain proteins: Overexpression of OBP3 leads to growth defects. Plant J. 2000, 21, 329-339. [CrossRef] [PubMed]

113. Castorina, G.; Fox, S.; Tonelli, C.; Galbiati, M.; Conti, L. A novel role for STOMATAL CARPENTER 1 in stomata patterning. BMC Plant Biol. 2016, 16, 172. [CrossRef] [PubMed]

114. Zhuo, M.; Sakuraba, Y.; Yanagisawa, S. A Jasmonate-activated MYC2-Dof2.1-MYC2 Transcriptional Loop Promotes Leaf Senescence in Arabidopsis. Plant Cell 2019, 32, 242-262. [CrossRef] [PubMed]

115. Gardiner, J.; Sherr, I.; Scarpella, E. Expression of DOF genes identifies early stages of vascular development in Arabidopsis leaves. Int. J. Dev. Biol. 2010, 54, 1389-1396. [CrossRef] [PubMed]

116. Wei, P.C.; Tan, F.; Gao, X.Q.; Zhang, X.Q.; Wang, G.Q.; Xu, H.; Li, L.J.; Chen, J.; Wang, X.C. Overexpression of AtDOF4.7, an Arabidopsis DOF family transcription factor, induces floral organ abscission deficiency in arabidopsis. Plant Physiol. 2010, 153, 1031-1045. [CrossRef]

117. Moreno-Risueno, M.Á.; Martínez, M.; Vicente-Carbajosa, J.; Carbonero, P. The family of DOF transcription factors: From green unicellular algae to vascular plants. Mol. Genet. Genom. 2007, 277, 379-390. [CrossRef]

118. Shigyo, M.; Tabei, N.; Yoneyama, T.; Yanagisawa, S. Evolutionary processes during the formation of the plant-specific dof transcription factor family. Plant Cell Physiol. 2007, 48, 179-185. [CrossRef]

(C) 2020 by the authors. Licensee MDPI, Basel, Switzerland. This article is an open access article distributed under the terms and conditions of the Creative Commons Attribution (CC BY) license (http://creativecommons.org/licenses/by/4.0/). 